\title{
Studies of Wound Healing Activity and Irritation Test of Chili (Capsicum frutescens L.) Leaves Gel on Rats (Rattus novergicus)
}

\section{(Studi Aktivitas Penyembuhan Luka Dan Uji Iritasi Gel Daun Cabai Rawit (Capsicum frutescens L.) pada Tikus (Rattus novergicus))}

\author{
Julianri Sari Lebang*, Jainer Pasca Siampa, Nurmiati \\ Program Studi Farmasi, Fakultas Matematika dan Ilmu Pengetahuan Alam, Universitas Sam Ratulangi, Manado, \\ Indonesia. \\ *E-mail: julianrilebang@unsrat.ac.id
}

\author{
Article Info: \\ Received: 10 January 2021 \\ in revised form: 14 March 2021 \\ Accepted: 31 March 2021 \\ Available Online: 31 March 2021 \\ Keywords: \\ Gel \\ Wound healing \\ Skin irritation \\ Corresponding Author: \\ Julianri Sari Lebang \\ Program Studi Farmasi \\ Fakultas MIPA \\ Universitas Sam Ratulangi \\ Manado \\ 95111 \\ Indonesia \\ email: julianrilebang@unsrat.ac.id
}

\begin{abstract}
Chili pepper (Capsicum frutescens L.) leaves have been used empirically as wound healing caused by sharp objects. Several studies showed that it has antibacterial and wound healing activities. This study aims to formulate gel from chili leaves extract, then determine wound healing activity and irritating properties on rat's skin. Gel was formulated by using various types and concentrations of gelling agents, consisted of Carbopol $0.5 \%, 0.75 \%, 1 \%$ and hydroxy propyl methyl cellulose at $2.5 \%, 5 \%$ and $7.5 \%$ respectively. Cycling test was conducted to determine the physical stabilities. The results showed that all formula has no altered on organoleptic properties and $\mathrm{pH}$ value. Gel of $0.5 \%$ Carbopol (F2) and $7.5 \%$ of HMPC (F5) has no change in spreadability and adhesion properties. Based on statistical analysis using paired t-test and one-way ANOVA, it concludes that F2 and F5 were physically stable and further evaluated as wound healer. Wound healer evaluation showed that the healing time (days) of Carbopol based gel (F2) was $10.2 \pm 1.26$ and HPMC based gel was $8 \pm 0.82$. The length of incision wound $(\mathrm{cm})$ at $8^{\text {th }}$ day was $0.5 \pm 0.183$ for $\mathrm{F} 2$ and $0.06 \pm 0.071$ for F5. Statistical analysis of healing time showed $\mathrm{p}<0.01$ and wound length showed $\mathrm{p}<0.05$ indicated that F5 (contained 5\% HPMC) was significantly different compared to negative control. The results of the irritation test showed that gel formulas were not causing erythema and edema on rat's skin. It can be concluded that gel of chili leaves extract that formulated with 5\% of HPMC has wound healing activity and safety to be used.
\end{abstract}




\begin{abstract}
ABSTRAK
Daun cabai (Capsicum frutescens L.) telah digunakan secara empiris sebagai penyembuh luka akibat benda tajam. Beberapa penelitian menunjukkan aktivitas antibakteri dan penyembuhan lukanya. Penelitian ini bertujuan untuk membuat gel dari ekstrak daun cabai dan menentukan aktivitas penyembuhan luka dan sifat iritasinya pada kulit tikus. Gel dibuat dengan menggunakan variasi jenis dan konsentrasi zat pembentuk gel, terdiri dari karbopol 0,5\%, 0,75\%,1\% dan hidroksi propil metil selulosa (HPMC) masing-masing 2,5\%, 5\% dan 7,5\%. Cycling Test dilgunakan untuk menentukan stabilitas fisiknya. Hasil penelitian menunjukkan bahwa semua formula tidak mengalami perubahan pada sifat organoleptik dan nilai $\mathrm{pH}$. Gel yang terbuat dari $0,5 \%$ karbopol (F2) dan 7,5\% HMPC (F5) tidak mengalami perubahan daya sebar dan daya rekat. Berdasarkan analisis statistik menggunakan uji-t berpasangan dan ANOVA satu arah diperoleh kesimpulan bahwa F2 dan F5 secara fisik stabil dan dapat dilanjutkan untuk evaluasi sebagai penyembuh luka. Evaluasi penyembuhan luka menunjukkan waktu penyembuhan (hari) untuk gel dasar karbopol (F2) adalah 10,2 \pm 1,26 dan gel berbasis HPMC $8 \pm 0,82$. Panjang luka sayatan $(\mathrm{cm})$ hari ke-8 adalah 0,5 $\pm 0,183$ untuk F2 dan 0,06 $\pm 0,071$ untuk F5. Analisis statistik untuk waktu penyembuhan menunjukkan $\mathrm{p}<0,01$ dan panjang luka menunjukkan p <0,05 yang berarti bahwa F5 yang mengandung 5\% HPMC berbeda nyata dibandingkan dengan kontrol negatif. Hasil uji iritasi menunjukkan bahwa semua formula gel tidak menyebabkan eritema dan edema pada kulit tikus. Dapat disimpulkan bahwa gel ekstrak daun cabai yang dibuat dengan HPMC 5\% memiliki aktivitas penyembuhan luka dan aman untuk digunakan.
\end{abstract}

Kata kunci: Cabai Rawit, Gel, Penyembuhan Luka, Iritasi Kulit

\title{
INTRODUCTION
}

Incision wound is a wound that occurs due to exposure to a sharp object that causes linear injury to the skin and underlying tissue. Data obtained by Basic Health Research (Riskesdas) showed that from 188 populations, $98.9 \%$ had experienced wounds. Approximately $60 \%$ of the total population has injuries to the legs, $22 \%$ to the stomach and $16 \%$ to experience acute injuries due to surgery (incision) or due to trauma. (Dinas Kesehatan Republik Indonesia, 2013).

Empirically, fruits of Capsicum frutescens L. are used to treat stomach spasms, skin infections and diarrhea. (Mutiara dan Uning, 2019). Besides of fruit, people in South Sulawesi use chili pepper leaves to stop bleeding and healing wounds caused by sharp objects. Wound healing activity is probably due to the secondary metabolites content of cayenne pepper which can inhibit the growth of infection-causing bacteria.

Numerous studies showed that chili leaves have antibacterial activity. Its leaves extract can inhibit Escherichia coli (Puji et al., 2016). The ethyl acetate fraction of chili leaves has a MIC value of $10 \%$ against pneumonia caused bacteria Klebsiella pneumonia (Fauzziya et al., 2017). Ethanol extract at a concentration of $5 \%$ has been shown to have healing activities for incision wounds (Pareang, 2017). Chili pepper leaves extract is also known to have antipyretic activity at a dose of $300 \mathrm{mg} / \mathrm{kg}$ animal body weight (Yuliana dan Khaerati, 2018).

Chili pepper leaves extract will be easier to be used if it is formulated into pharmaceutical dosage forms. This study is aims to formulate a gel preparation from chili pepper leaves extract that is physically stable and determine the effectiveness and safety of the gel as an incision wound healer. 


\section{MATERIAL AND METHOD}

\section{Material}

Chili pepper leaves, ethanol 70\%, Carbopol 940, Hydroxy propyl methyl cellulose (HPMC), propylene glicol, triehtanolamine, DMDM Hydantoin, aquadest, universal $\mathrm{pH}$ papers, and Bioplacenton ${ }^{\circledR}$ gel.

\section{Methods}

\section{Plant Collection and Extraction}

Chili pepper leaves are obtained from Langoan, Minahasa Regency, North Sulawesi. Leaves were washed by using running water and then dried at $40-50^{\circ} \mathrm{C}$ temperature. The dried leaves were then crushed to obtain the simplicia. The extraction process was carried out by maceration method using $70 \%$ ethanol for 4 days. Filtrate from maceration and re-maceration process were collected and then evaporated to get a thick mass of extract.

\section{Formulation of Gel}

Gel was consisted of excipients and chili leaves extract based on the formula in Table 1. The gel base was made by dispersing HPMC and Carbopol into aquadest at $70^{\circ} \mathrm{C}$ temperature, then leaved it for 24 hours until swelling. The mass was stirred until homogeneous. Furthermore, propylenglycol and DMDM Hydantoin were added and stirred. Extract was added to the gel base mixture then stirred until it was homogeneous while adding TEA to form a gel mass (Putra, 2016).

Table 1. Formula of gel contain chili pepper leaves extract

\begin{tabular}{ccccccc}
\hline \multirow{2}{*}{ Component } & \multicolumn{7}{c}{ Concentration } \\
\cline { 2 - 7 } & $\mathrm{F} 1$ & $\mathrm{~F} 2$ & $\mathrm{~F} 3$ & $\mathrm{~F} 4$ & $\mathrm{~F} 5$ & $\mathrm{~F} 6$ \\
\hline $\begin{array}{c}\text { Exract } \\
\text { Carbopol 940 }\end{array}$ & $5 \%$ & $5 \%$ & $5 \%$ & $5 \%$ & $5 \%$ & $5 \%$ \\
Hydroxypropylmethylcelullose & - & - & & $0,5 \%$ & $0,75 \%$ & $1 \%$ \\
(HPMC) & $2,5 \%$ & $5 \%$ & $7,5 \%$ & - & - & - \\
DMDM Hydantoin & $0,5 \%$ & $0,5 \%$ & $0,5 \%$ & $0,5 \%$ & $0,5 \%$ & $0,5 \%$ \\
Propyleneglycol & $15 \%$ & $15 \%$ & $15 \%$ & - & - & - \\
Triethanolamine (TEA) & $10 \mathrm{gtt}$ & $10 \mathrm{gtt}$ & $10 \mathrm{gtt}$ & $5 \mathrm{gtt}$ & $5 \mathrm{gtt}$ & $5 \mathrm{gtt}$ \\
Aquadest & $\mathrm{ad} 100$ & $\mathrm{ad} \mathrm{100}$ & $\mathrm{ad} 100$ & $\mathrm{ad} \mathrm{100}$ & $\mathrm{ad} \mathrm{100}$ & $\mathrm{ad} \mathrm{100}$ \\
\hline
\end{tabular}

\section{Physical Evalution of Gel}

Physical evaluation of gel preparations includes organoleptic test, homogeneity, $\mathrm{pH}$ measurement, dispersion, and adhesion (Tambunan \& Sulaiman, 2018).

\section{Cycling Test}

Gel preparation was put in a tightly container then put in a refrigerator at $-8^{\circ} \mathrm{C}$ for 24 hours. After that, it was placed at room temperature of $40^{\circ} \mathrm{C}$ for 24 hours $(1$ cycle). This stability test was carried out in 5 cycles. Gel preparation was then evaluated for its physical properties according to the physical evaluation procedures. 


\section{Wound Healing Activity}

Wound healing activity was evaluated by using white rats weighing 180-200 grams. All effectiveness study procedures have received ethical approval by Health Research Ethics Committee of Manado Health Polytechnic, The Ministry of Health No. KEPK.01/09/070/2020. The experimental animals were randomly divided into 4 groups, negative control group, the positive control group (Bioplacenton ${ }^{\circledR}$ gel), and 2 groups given by chili leaves gel with different types of bases. The back of the test animal was cleaned from hair and then made an incision wound with a length of $2 \mathrm{~cm}$ and a depth of $2 \mathrm{~mm}$ using a scalpel. Gel was then applied to incision wound as much as 0.1 gram every 24 hours and then covered with sterile gauze. Observation of the wound healing process was carried out for 7-14 days by measuring the length of the wound every day (Putrianirma et al., 2019).

\section{Skin Irritation Test}

The back of the rats were shaved $2 \times 2 \mathrm{~cm}$ wide, then applied with a special hair removal cream to clean the remaining hair. The clean skin the left on for 24 hours to observed any cuts or erythema formed as a result of shaving. Gel preparation based on HPMC and carbopol are then applied to the test area as much as 0.25 grams. The test area is then covered with gauze and plaster. Observation of erythema and edema was carried out at intervals of 24, 48 and 72 hours. Erythema and edema appearing were recorded and scored according to Table 2 (Kuncari et al., 2015).

Table 2. Grading Scale for Skin Condition for Irritation Test

\begin{tabular}{cccc}
\hline Erythema & \multicolumn{1}{c}{ Edema } \\
\hline Condition of skin & Score & Condition of skin & Score \\
Non-erythema & 0 & Non edema & 0 \\
Minimally erythema & 1 & Minimally edema & 1 \\
Moderate erythema & 2 & Moderate edema & 2 \\
Severe erythema & 3 & Severe udema $( \pm 1$ mm of thickness) & 3 \\
Extremely erythema & 4 & Extremely edema (>1 mm of thickness) & 4 \\
\hline
\end{tabular}

Score that obtained were used to determine the primary irritation index using a formula:

Primary Irritation index $=\frac{\text { the total value of erythema and edema observations }}{\text { number of mice } \mathrm{x} \text { number of observation time }}$

\section{RESULT AND DISCUSSION}

The extraction method of maceration was chosen to extract the chili pepper leaves. This method was appropriate because the stability of the active compounds in the simplicia on high temperature is unknown. This method is also suitable for leaves consistency which is softer than other parts of the plant such as seeds or stems. The rendemen from the extraction process was $20.31 \%$.

Gel preparations were evaluated for their physical properties before and after Cycling Test. Organoleptic gel testing included color, consistency and odor, which did not change before and after the stability test. The homogeneity test also showed no change before and after the stability 
test. This shows that the organoleptic and homogeneity of the gel were not change after being stored at different temperatures. Organoleptic and homogeneity test results are presented in Table 3.

Table 3. Organoleptic Evaluation Results and Gel Homogeneity Before and After Cycling Test.

\begin{tabular}{|c|c|c|c|c|c|c|c|c|}
\hline \multirow{3}{*}{ Formula } & \multicolumn{8}{|c|}{ Parameter } \\
\hline & \multicolumn{2}{|c|}{ Colour } & \multicolumn{2}{|c|}{ Consistency } & \multicolumn{2}{|c|}{ Smell } & \multicolumn{2}{|c|}{ Homogeneity } \\
\hline & Before & After & Before & After & Before & After & Before & After \\
\hline $\mathrm{F} 1$ & $\begin{array}{c}\text { Greenish } \\
\text { brown }\end{array}$ & $\begin{array}{l}\text { Greenish } \\
\text { brown }\end{array}$ & Thin & Thin & $\begin{array}{c}\text { smell of the } \\
\text { extract }\end{array}$ & $\begin{array}{c}\text { smell of the } \\
\text { extract }\end{array}$ & $\begin{array}{l}\text { Homogene } \\
\text { ous }\end{array}$ & $\begin{array}{l}\text { Homogen } \\
\text { eous }\end{array}$ \\
\hline $\mathrm{F} 2$ & $\begin{array}{c}\text { Greenish } \\
\text { brown }\end{array}$ & $\begin{array}{l}\text { Greenish } \\
\text { brown }\end{array}$ & Thick & Thick & $\begin{array}{l}\text { smell of the } \\
\text { extract }\end{array}$ & $\begin{array}{c}\text { smell of the } \\
\text { extract }\end{array}$ & $\begin{array}{l}\text { Homogene } \\
\text { ous }\end{array}$ & $\begin{array}{c}\text { Homogen } \\
\text { eous }\end{array}$ \\
\hline $\mathrm{F} 3$ & $\begin{array}{c}\text { Greenish } \\
\text { brown }\end{array}$ & $\begin{array}{l}\text { Greenish } \\
\text { brown }\end{array}$ & Thick & Thick & $\begin{array}{l}\text { smell of the } \\
\text { extract }\end{array}$ & $\begin{array}{c}\text { smell of the } \\
\text { extract }\end{array}$ & $\begin{array}{c}\text { Homogene } \\
\text { ous }\end{array}$ & $\begin{array}{c}\text { Homogen } \\
\text { eous }\end{array}$ \\
\hline $\mathrm{F} 4$ & $\begin{array}{c}\text { Greenish } \\
\text { brown }\end{array}$ & $\begin{array}{l}\text { Greenish } \\
\text { brown }\end{array}$ & Thin & Thin & $\begin{array}{l}\text { smell of the } \\
\text { extract }\end{array}$ & $\begin{array}{c}\text { smell of the } \\
\text { extract }\end{array}$ & $\begin{array}{l}\text { Homogene } \\
\text { ous }\end{array}$ & $\begin{array}{l}\text { Homogen } \\
\text { eous }\end{array}$ \\
\hline F5 & $\begin{array}{c}\text { Greenish } \\
\text { brown }\end{array}$ & $\begin{array}{c}\text { Greenish } \\
\text { brown }\end{array}$ & Thick & Thick & $\begin{array}{l}\text { smell of the } \\
\text { extract }\end{array}$ & $\begin{array}{c}\text { smell of the } \\
\text { extract }\end{array}$ & $\begin{array}{l}\text { Homogene } \\
\text { ous }\end{array}$ & $\begin{array}{c}\text { Homogen } \\
\text { eous }\end{array}$ \\
\hline F6 & $\begin{array}{c}\text { Greenish } \\
\text { brown }\end{array}$ & $\begin{array}{c}\text { Greenish } \\
\text { brown }\end{array}$ & Thick & Thick & $\begin{array}{c}\text { smell of the } \\
\text { extract }\end{array}$ & $\begin{array}{c}\text { smell of the } \\
\text { extract }\end{array}$ & $\begin{array}{l}\text { Homogene } \\
\text { ous }\end{array}$ & $\begin{array}{c}\text { Homogen } \\
\text { eous }\end{array}$ \\
\hline
\end{tabular}

F1 : Gel Base Carbopol 0,5\%, F2 : Gel Base Carbopol 0,75\%, F3 : Gel Base Carbopol 1\%, F4 : Gel Base HMPC 2,5\%, F5 : Gel Base HPMC 5\%, F6 : Gel Base HPMC 7,5\%.

Table 2 showed that the consistency of F1 and F4 that contain less concentration of polymer $(0.5 \%$ carbopol and 2.5\% HPMC) have a thin consistency. Consistency of the carbopol based gel is affected by the concentration of polymer and TEA added to the formula. The increasing in carbopol concentration caused three dimension gel network of fibers become thicker. In low concentration of Carbopol polymer, three dimension gel networks become irregular network that makes thin consistency (Kim et al., 2003). HPMC as cellulose derivate can swell in aqueous solution by making hydrogen bonds with hydroxyl groups from water. Higher concentration of HMPC in formula causes more hydrogen bonds, that make thicker structure of gel. In other hands, low concentration of polymer showed thin structure of gel (Ardana et al., 2015).

Table 4. pH Evaluation, spreadability and gel adhesion before and after the cycling test.

\begin{tabular}{ccccccc}
\hline \multirow{2}{*}{ Formula } & \multicolumn{5}{c}{ Parameter } \\
\cline { 2 - 7 } & \multicolumn{2}{c}{$\mathrm{pH}$} & \multicolumn{2}{c}{ Spreadability $\left(\mathrm{cm}^{2}\right)$} & \multicolumn{2}{c}{ Gel adhesion (second) } \\
\cline { 2 - 7 } & Before & After & Before & After & Before & After \\
\hline F1 & $5.67 \pm 0.58$ & $5.67 \pm 0.58$ & $28.55 \pm 2.41$ & $33.67 \pm 5.72$ & $3.66 \pm 0.60$ & $2.75 \pm 0.75^{*}$ \\
F2 & $5.00 \pm 0.00$ & $5.00 \pm 0.00$ & $17.85 \pm 4.44$ & $19.67 \pm 2.34$ & $8.38 \pm 3.36$ & $8.61 \pm 2.22$ \\
F3 & $5.00 \pm 0.00$ & $5.00 \pm 0.00$ & $9.06 \pm 1.45$ & $10.64 \pm 0.73$ & $11.31 \pm 2.53$ & $11.28 \pm 3.60$ \\
F4 & $5.67 \pm 0.58$ & $5.67 \pm 0.58$ & $31.41 \pm 6.96$ & $26.05 \pm 4.56$ & $6.73 \pm 0.45$ & $4.56 \pm 1.12$ \\
F5 & $5.00 \pm 0.00$ & $5.00 \pm 0.00$ & $13.41 \pm 0.38$ & $12.00 \pm 3.62$ & $12.73 \pm 4.59$ & $12.18 \pm 2.88$ \\
F6 & $6.00 \pm 1.00$ & $5.00 \pm 0.00$ & $7.88 \pm 0.70$ & $12.10 \pm 0.46^{*}$ & $18.84 \pm 3.20$ & $15.55 \pm 3.46^{*}$ \\
\hline
\end{tabular}

*) significant different between parameter before and after cycling test using paired t-test at $\mathrm{p}<0.05$

Topical preparations must have a $\mathrm{pH}$ value that not irritating the skin, which is in the range of 4.5 6.5 (Kuncari et al., 2015). Table 3 shows that all gel preparations have a $\mathrm{pH}$ value in the range 5 6 , which means that all formulas met the requirements. Measurement of $\mathrm{pH}$ after the cycling test 
showed the gel based on HPMC 7.5\% change in $\mathrm{pH}$ from 6 to 5 . The alteration of $\mathrm{pH}$ is still in the range of $\mathrm{pH}$ requirements for topical preparations. Statistical analysis using paired t-test describes that alteration of $\mathrm{pH}$ value before and after cycling test is nonsignificant.

The spreadability of gel preparation was carried out by applying the same load to all gel formulas and counted its diameter and width of spread. Spreadability of topical preparations indicates that gel is easy to disperse and helping in uniform application on the skin. The spreadability of gel before cycling test showed that the higher the concentration of the gelling agent, the smaller the spread area of the gel preparation. Increasing the concentration of gelling agent causes the gel to become thicker so that its spreading power decreases (Daood et al., 2019). Spreadability evaluation showed that spreadability value of formula are varied, range of $9-29 \mathrm{~mm}^{2}$ for carbopol based gel, and $7-$ $31 \mathrm{~mm}^{2}$ for HPMC based gel. After stability test, spreadability for F1 - F5 is altered but the alteration is not significant (paired t-test at $\mathrm{p}<0.05^{*}$ ). Exception for $\mathrm{F} 6$ that have changed in spreadability after cycling test.

The test for the adhesion of the gel preparations showed that increasing the concentration of the polymer is to increase gel adhesion. Hydrogel-based gelling agents such as Carbopol and cellulose derivatives will develop due to absorbing the dispersing liquid to form a colloidal mass which will affect the viscosity (Sailaja. et al., 2015). The thick mass of this gel preparation will increase the stickiness of the gel thereby increasing its adhesion. Table 4 showed that F1 and F4 that contained minimum concentration of polymer showed less adhesion value compares with other gel that have the same polymer. It may correlate with the concentration of polymer that can make thin gel network (Ardana et al., 2015; Kim et al., 2003). Topical preparation should have adhesion value at more than 4 seconds (Lestari et al., 2017). In table 4, we can see that F2, F3, F4, F5 and F6 fulfilled the requirement of adhesion value, but F6 showed a decrease in adhesion that indicated that F6 are altered after cycling test.

All physical evaluation of six formula is intended to get the best formula from each variation of polymer base (carbopol and HPMC) then determined their wound healing activity. First, we evaluated $\mathrm{pH}$ value, spreadability and adhesion parameter of Carbopol based gel using one way ANOVA to determine differences between three formula after cycling test. $\mathrm{pH}$ value is non significantly difference between F1, F2 and F3 at $\mathrm{p}<0.01$. Spreadability of Carbopol based gel is significantly different between formula at $\mathrm{p}=0.00$ and $\mathrm{p}=0.008(\mathrm{p}<0.01)$, and adhesion value of $\mathrm{F} 2$ and F3 is not significantly difference at $\mathrm{p}=0.221$ ( $\mathrm{p}>0.01)$. F1 showed significant different in adhesion to other Carbopol based formula, but it adhesion alters after stability test that indicated it is not stable for storage. From organoleptic parameter and supported by statistical analysis, we conclude that F2 that contain $0.75 \%$ Carbopol have good physical stability. 
As much as carbopol based gel, physical parameter of HMPC based gel was analyzed to establish physically stable formula. $\mathrm{pH}$ value between three formula gel contains HPMC are not significantly different at $\mathrm{p}<0.01$. The spreadability value is not significant between F5 (5\% HMPC) and F6 (7.5\% HPMC) at $\mathrm{p}=0.972$ ( $\mathrm{p}>0.01)$. Adhesion parameter of HPMC based formula is also not significantly different between F5 and F6 but F6 showed change in adhesion after cycling test (Table 4). Formula 5 that contain 5\% HPMC showed no change in organoleptic parameter, $\mathrm{pH}$, spreadibility and adhesion (Table 3 and table 4). As much as F5, F4 that contain 2.5\% HMPC showed no change in $\mathrm{pH}$, spreadability and adhesion parameter before and after cycling test, but it has a thin consistency. Topical preparation of gel should has the proper consistency so it can be easily flow from the tube and has sufficient viscosity when applied on the skin and not flowing off after application ( $\mathrm{J}$ Mastropietro, 2013). Based on the result of the physical stability evaluation of formula, it can be said that gel contains Carbopol 0.75\% (F2) and HPMC 5\% (F5) could follow evaluation of wound healing activity.

Wound healing activity of gel preparations was determined by measuring the reduction in wound length and duration of healing time expressed in days. Animals were cured if the scab that formed on the wound was removed (Figure 1). It can be seen that the positive control group had the fastest healing time, followed by the group that was given 5\% HPMC gel, 0.75\% Carbopol gel, and negative control. The average of wound healing time can be seen in Table 5 .

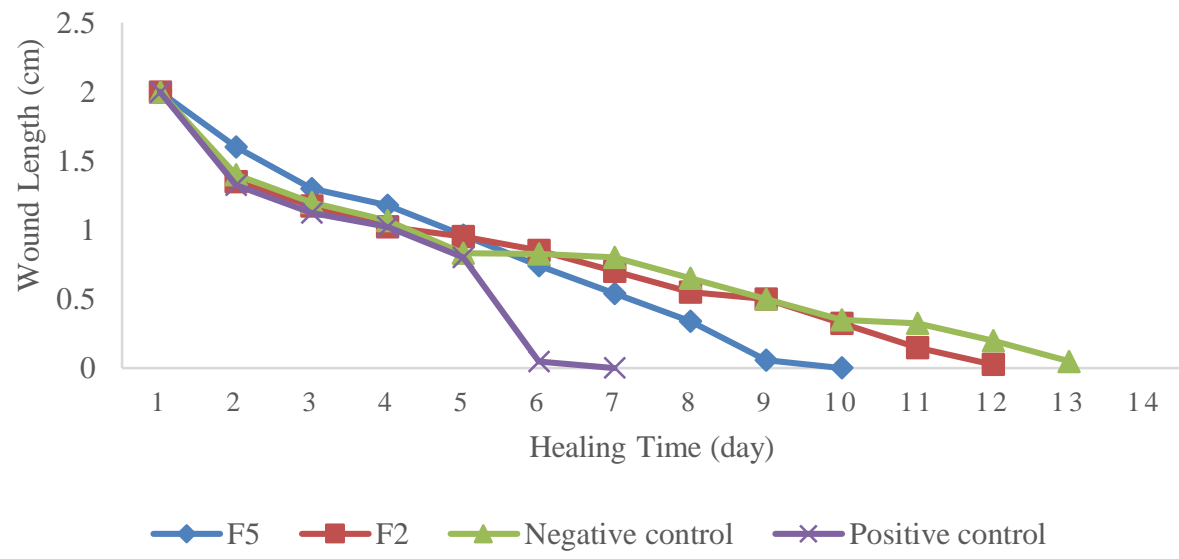

Figure 1. Healing time vs wound length. F2: Chili pepper leaves gel with Carbopol base of 0.75\% ; F5: Chili pepper leaves gel with 5\% HPMC base.

Tabel 5. Mean of incision wound length on day $1^{\text {st }}, 8^{\text {th }}$ and $12^{\text {th }}$

\begin{tabular}{lccc}
\hline \multirow{2}{*}{ Groups } & \multicolumn{3}{c}{ Incision length (cm) in day- } \\
\cline { 2 - 4 } & 1 & 8 & 13 \\
\hline Negative Control & $1.4 \pm 0.082$ & $0.5 \pm 0.216$ & $0.05 \pm 0.1$ \\
Positive Control & $1.33 \pm 0.263$ & $0.00 \pm 0.00^{*}$ & $0.00 \pm 0.00$ \\
Gel base 0,75\% Carbopol base (F2) & $1.35 \pm 0.1$ & $0.5 \pm 0.183$ & $0.00 \pm 0.00$ \\
Gel base 5\% HPMC (F5) & $1.6 \pm 0.071$ & $0.06 \pm 0.134^{*}$ & $0.00 \pm 0.00$ \\
\hline
\end{tabular}

*) Significant towards negative control group at p <0.05. F2: Gel with 0.75\% cabopol base; F5: Gel with 5\% HPMC base. 
Table 6. Incision Wound in Rats

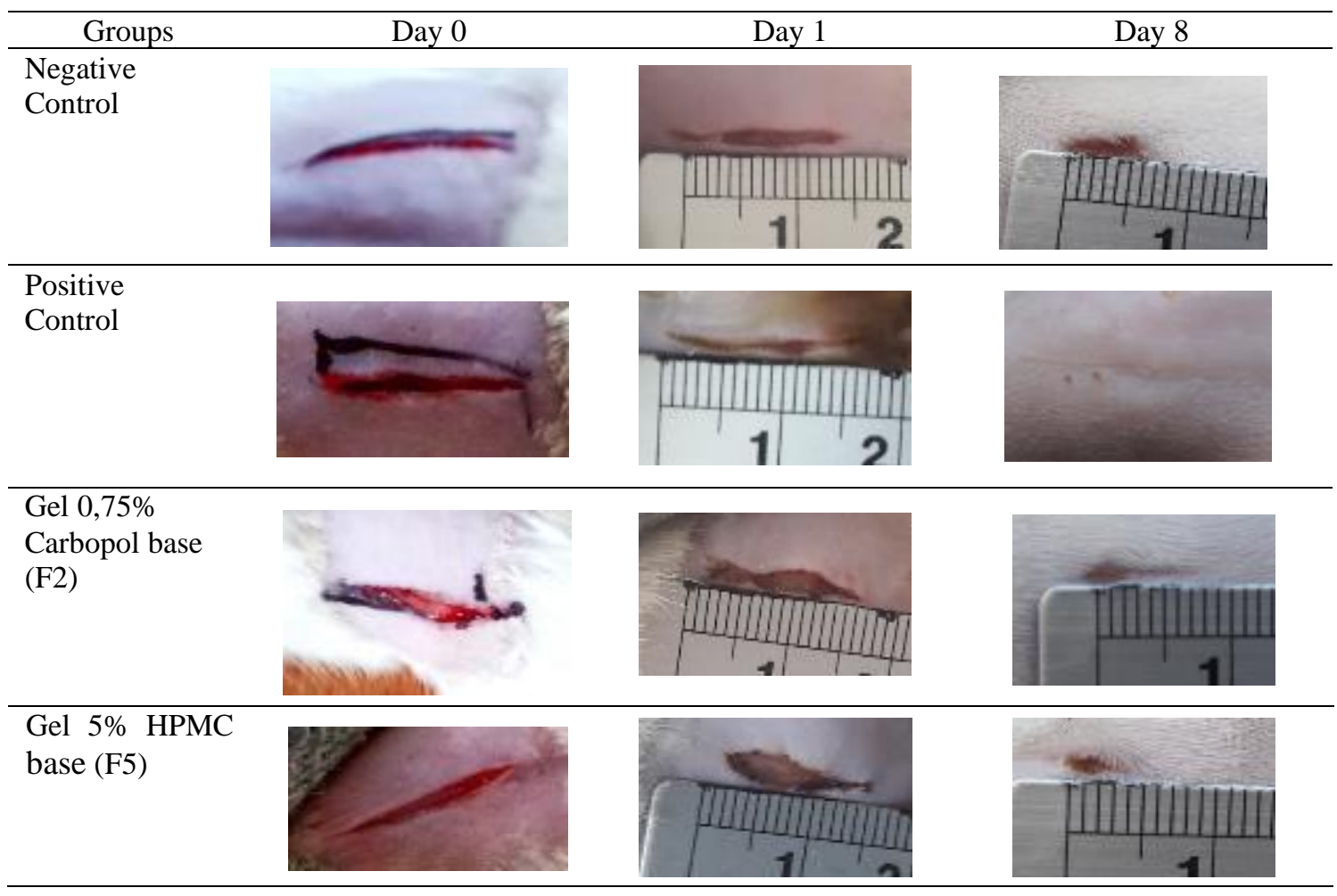

Table 7. Healing time of incision wound healing in rats

\begin{tabular}{lccccc}
\hline \multirow{2}{*}{ Groups } & \multicolumn{4}{c}{ Healing time (days) per animal } & Mean \pm deviation \\
\cline { 2 - 5 } & 1 & 2 & 3 & 4 & standard \\
\hline Negative Control & 12 & 12 & 12 & 13 & $11.8 \pm 0.5$ \\
Positive Control & 5 & 5 & 6 & 5 & $6.6 \pm 0.5^{* *}$ \\
Gel base 0,75\% Carbopol base (F2) & 12 & 9 & 11 & 11 & $10.2 \pm 1.26$ \\
Gel base 5\% HPMC (F5) & 8 & 8 & 7 & 9 & $8 \pm 0.82^{* *}$ \\
\hline
\end{tabular}

**)Significant towards the negative control group at p <0.01. F2: Gel with 0.75\% Carbopol base; F5: Gel with 5\% HPMC base.

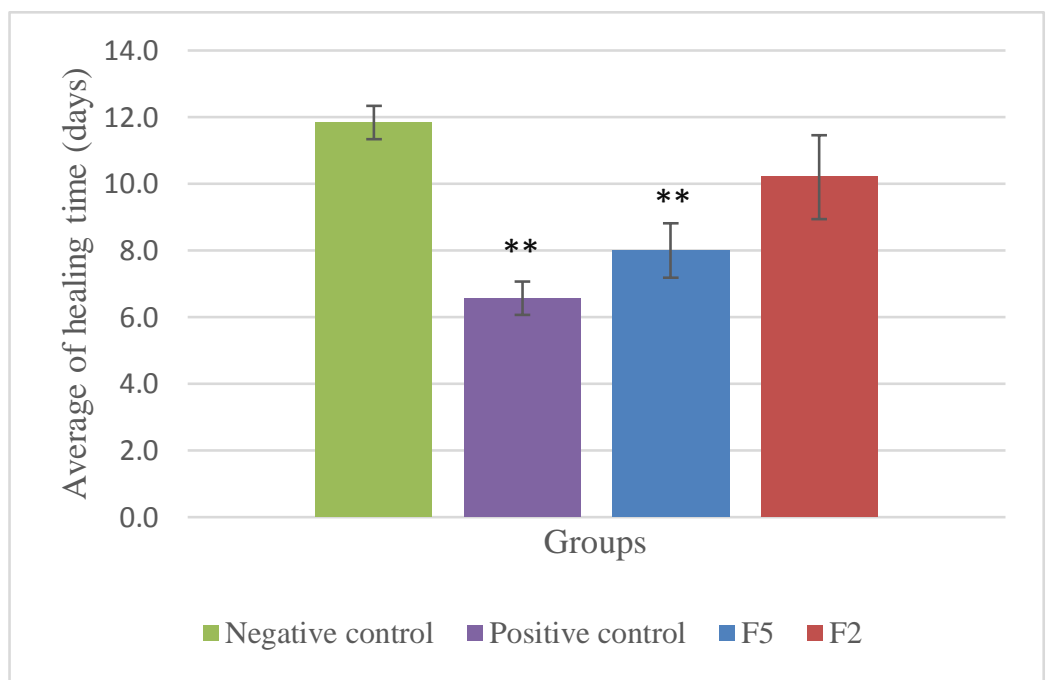

Figure 2. The average of healing time in rats. $* *)$ Significant to the negative control group at $\mathrm{p}$ $<0.01 ;$ F2: Chili pepper leaves gel with carbopol base of $0.75 \%$; F5: Chili pepper leaves gel with 5\% HPMC base. 
Statistical analysis of the length of the incision wound and healing time for each treatment group in Table 5 and 7 showed that the group given gel contain HPMC 5\% has a significant difference with the negative control at a significance value of $\mathrm{p}<0.05$ and $<0.01$. The better wound healing activity of F5 than F2 is probably due to F5 contains HPMC base that has greater adhesion than the Carbopol base. Adhesion, influenced by the viscosity of the gel, can affect the duration of contact between the active substance in the gel preparation and the skin surface (Glogowski et al., 2015). The longer contact time allows the active ingredients to be in longer contact with the wounded skin so that it can accelerate the wound healing.

An irritation test for topical preparation of gels was carried out to determine the safety of using the preparation. The irritation test was performed by observing the appearance of erythema and edema in the area that gel preparation was applied. The value obtained was used to calculate the irritation index of the preparation (Kuncari et al., 2015). The irritation index category of the preparation can be seen in Table 6, while the results of the irritation test can be seen in Tables 7 and 8 .

Table 8. Primary Irritation Index Category

\begin{tabular}{cc}
\hline Category & Primary Irritation Index \\
\hline Non-irritating & $0-0,4$ \\
Minimally irritating & $0,5-1,9$ \\
Moderate irritating & $2-4,9$ \\
Severe irritating & $5,0-8,0$ \\
\hline
\end{tabular}

Table 9. Primary Irritation Index Value of Chili pepper leaves gel

\begin{tabular}{|c|c|c|c|c|c|c|}
\hline \multirow{2}{*}{ Groups } & \multicolumn{3}{|c|}{ Erythema } & \multicolumn{3}{|c|}{ Edema } \\
\hline & 24 hours & 48 hours & 72 hours & 24 hours & 48 hours & 72 hours \\
\hline $\begin{array}{lll}\text { Carbopol } & 0,75 \% & \text { without } \\
\text { extract }\end{array}$ & 0 & 0 & 0 & 0 & 0 & 0 \\
\hline HPMC 5\% without extract & 0 & 0 & 0 & 0 & 0 & 0 \\
\hline $\mathrm{F} 2$ & 0 & 0 & 0 & 0 & 0 & 0 \\
\hline F5 & 0 & 0 & 0 & 0 & 0 & 0 \\
\hline Primary Irritation Index & & 0 & & & 0 & \\
\hline
\end{tabular}

Table 10. Skin Condition as Value of Skin Irritation Test

\begin{tabular}{|c|c|c|c|}
\hline Groups & 24 hours & 48 hours & 72 hours \\
\hline $\begin{array}{l}\text { Carbopol } 0,75 \\
\% \text { without } \\
\text { extract }\end{array}$ & & & \\
\hline $\begin{array}{l}\text { HPMC 5\% } \\
\text { without extract }\end{array}$ & & & 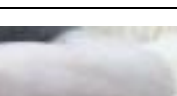 \\
\hline
\end{tabular}




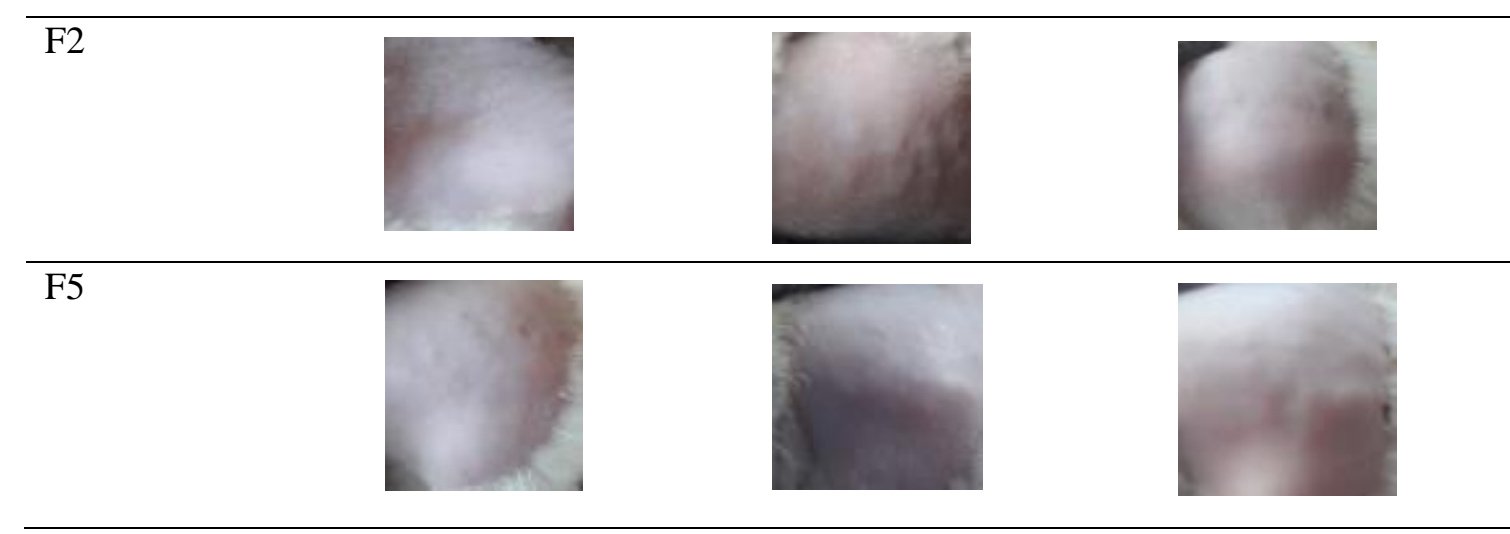

The results of the irritation test for chili pepper leaves gel with two different types of bases showed that the two gel formulas had an irritation index of 0 (non-irritating). The irritation index value of the base gel without extract showed the same value. It indicated that the chili pepper leaves gel formulated with $0.75 \%$ Carbopol and 5\% HPMC are safe to be used. The irritation index value of the gel bases without extract showed that the bases are safe to be used because their types and concentrations used in the formula have no irritant effect (Rowe, 2009). Besides, the pH of preparation meet the requirement of proper topical preparation. $\mathrm{pH}$ also makes these gels have no irritation effect. This indicated that the addition of the extract to the gel base did not change the safety of the gel preparation.

\section{CONCLUSION}

It can be concluded that chili pepper leaves gel formulated with 5\% HPMC has the best wound healing activity and it has not irritating on the rats skin as well.

\section{ACKNOWLEDGEMENT}

The authors are grateful to LPPM Sam Ratulangi University that has funded this research.

\section{REFERENCES}

A. K. sailaja, Fauzziya, R., Nurani, L., Sulistyani, N., Dinas Kesehatan Republik Indonesia, Ardana, M., Aeyni, V., Ibrahim, A., Lindgreen, A., Lindgreen, A., Gurnani, N., Gupta, M., Mehta, D., Mehta, B. K., Al-snafi, A. E., Tambunan, S., Sulaiman, T. N. S., WesoŁowska, A., Jadczak, D., ... Dwita, L. P. (2015). Formulasi Gel Minyak Atsiri Sereh dengan Basis HPMC dan Karbopol. Food Science and Technology, 10(2), 1-46. https://doi.org/10.1023/B

Ardana, M., Aeyni, V., \& Ibrahim, A. (2015). Formulasi dan optimasi basis gel HPMC (Hidroxy Propyl Methyl Cellulose) Dengan Berbagai Konsentrasi. Journal of Tropical Pharmacy and Chemistry, 3(2), 101-108.

Daood, N. M., E Jassim, Z., M Gareeb, M., \& Zeki, H. (2019). Studying the Effect of Different Gelling Agent on the Preparation and Characterization of Metronidazole As Topical Emulgel. Asian Journal of Pharmaceutical and Clinical Research, March, 571-577. https://doi.org/10.22159/ajpcr.2019.v12i3.31504 
Dinas Kesehatan Republik Indonesia. (2013). Riset Kesehatan Dasar. Diabetes Mellitus, 87-90. https://doi.org/1 Desember 2013

Fauzziya, R., Nurani, L., \& Sulistyani, N. (2017). Penelusuran Senyawa Aktif Antibakteri Ekstrak Daun Cabai Rawit (Capsicum frutescens L.) terhadap Klebsiella pneumoniae dan Mekanisme Kebocoran Sel. 22(3), pp. 166-174.

Glogowski, A., Kolodziejska, J., Kolodziejczyk, M. K., \& Zgoda, M. M. (2015). The Influence Of The Viscosity Of The Ointment Vehicles Magisterial Topical Preparations, On The Speed Transfer Of Biologically Active Substances. Current Issues in Pharmacy and Medical Sciences, 28(3), 212-217. https://doi.org/10.1515/cipms-2015-0075

J Mastropietro, D. (2013). Rheology in Pharmaceutical Formulations-A Perspective. Journal of Developing Drugs, 02(02), 2-7. https://doi.org/10.4172/2329-6631.1000108

Kim, J. Y., Song, J. Y., Lee, E. J., \& Park, S. K. (2003). Rheological properties and microstructures of Carbopol gel network system. In Colloid and Polymer Science (Vol. 281, Issue 7, pp. 614623). https://doi.org/10.1007/s00396-002-0808-7

Kuncari, E. S., Iskandarsyah, I., \& Praptiwi, P. (2015). Uji Iritasi Dan Aktivitas Pertumbuhan Rambut Tikus Putih: Efek Sediaan Gel Apigenin Dan Perasan Herba Seledri (Apium graveolens L.). Media Penelitian Dan Pengembangan Kesehatan, 25(1), 15-22. https://doi.org/10.22435/mpk.v25i1.4092.15-22

Lestari, T., Yunianto, B., \& Winarso, A. (2017). Evaluasi Mutu Salep Dengan Bahan Aktif Temugiring, Kencur Dan Kunyit. Jurnal Kebidanan Dan Kesehatan Tradisional, 2(1), 8-12. https://doi.org/10.37341/jkkt.v2i1.34

Mutiara Uning, E. V. R. (2019). Uji Aktivitas Teh Herbal Daun Cabai Rawit (Capsicum frutescens. L.) Sebagai Penurun Kolesterol Dan Glukosa Secara In Vitro. Cendekia Eksakta, Vol 4, No 2 (2019), 80-85. https://publikasiilmiah.unwahas.ac.id/index.php/CE/article/view/3047

Pareang, L. (2017). Uji Aktivitas Penyembuhan Luka Insisi Ekstrak Etanol Daun Cabai Rawit (Capsicum frutescents L.) Pada Tikus Putih (Rattus norvegicus). Sekolah Tinggi Ilmu Farmasi Makassar.

Puji, A., Abdur, L., \& Indra, R. (2016). Aktivitas Ekstrak Daun Cabe Rawit (Capsicum frutescens L.) Terhadap Penghambatan Pertumbuhan Bakteri Escherichia coli Secara Invitro. Jurnal Farmasi Sains dan Praktis, I(2), 1-6.

Putra, S. K. B. (2016). Optimasi Formula Gel Hand Sanitizer Minyak Atsiri Jeruk Bergamot Dengan Komposisi HPMC dan Propilen Glikol. Universitas Sanata Dharma Yogyakarta, 1, 1-76. https://repository.usd.ac.id/4598/2/128114101_full.pdf

Putrianirma, R., Triakoso, N., Yunita, M. N., Yudaniayanti, I. S., Hamid, I. S., \& Fikri, F. (2019). Efektivitas Ekstrak Daun Afrika (Vernonia amygdalina) Secara Topikal Untuk Reepitelisasi Penyembuhan Luka Insisi Pada Tikus Putih (Rattus novergicus). Jurnal Medik Veteriner, 2(1), 30. https://doi.org/10.20473/jmv.vol2.iss1.2019.30-35 
Rowe, R. . (2009). Handbook of Pharmaceutical Excipient (6th ed.).

Tambunan, S., \& Sulaiman, T. N. S. (2018). Formulasi Gel Minyak Atsiri Sereh dengan Basis HPMC dan Karbopol. Majalah Farmaseutik, 14(2), 87-95.

Yuliana, I., \& Khaerati, K. (2018). Efek Antipiretik Ekstrak Daun Cabe Rawit (Capsicum annum L.) Terhadap Tikus Putih Jantan (Rattus norvegicus) Yang Diinduksi Vaksin Difteri Pertusis Tetanus. Biocelebes, 12, 65-70. 